\title{
Acetoine and chitinase production by native rizobacteria from Western Paraná
}

João Paulo Silva Monteiro ${ }^{1}$, Anderson José Scherer ${ }^{2}$, Lucas Mateus Hass ${ }^{3}$, Luana Patrícia Pinto Korber ${ }^{4}$, Guilherme Peixoto de Freitas ${ }^{3}$, Vivian Carré-Missio ${ }^{3}$, Marco Antônio Bacellar Barreiros ${ }^{3}$, Isac George Rosset ${ }^{3}$, Luciana Grange ${ }^{3}$.

${ }^{1}$ Universidade Estadual de Londrina - UEL, Londrina, PR. ${ }^{2}$ Universidade Federal do Rio Grande do Sul -UFRGS, ${ }^{3}$ Universidade Federal do Paraná - UFPR, ${ }^{4}$ Universidade Estadual do Oeste do Paraná - UNIOESTE, Cascavel - PR. Email: luana.kozak@gmail.com

\begin{abstract}
The objective of this study was to investigate 28 strains of native rhizobacteria from the west region of Paraná, evaluating the acetoin and chitinase production capacity, because of their role in biocontrol. The bacteria isolates were submitted to the modified Voges-Proskauer (VP) assay in Clark \& Lubs liquid medium for glucose fermentation. Metabolite production was evaluated in a spectrophotometer, and it showed a wide variation in concentrations $(0,476$ to 1,865$)$ for different isolates. Strains $241,320,326$, and 273 showed higher values than the others tested. According to positive results in the qualitative test of VP, 11 isolates were chosen for the tests in minimal medium containing chitin as the only source of carbon. Isolates that presented the degradation halo formation were considered as chitinolytic bacteria, evidencing chitinase activity. Among these strains, two belonged to the genus Bacillus spp. (56 and 121) and two to the genus Enterobacter spp. (292 and 151). Therefore, the present work was able to identify native strains with potential for biocontrol studies allowing to continue investigations of other metabolites produced by those bacteria in this collection regarding plant protection.
\end{abstract}

Keywords: biocontrol; chitin degradation; PGPB.

\section{Produção de acetoína e quitinase por rizobactérias nativas do Oeste do Paraná}

\section{Resumo}

O objetivo deste estudo foi investigar 28 cepas de rizobactérias nativas da região oeste do Paraná, avaliando a capacidade de produção de acetoína e quitinase, devido ao seu papel no biocontrole. Os isolados de bactérias foram submetidos ao ensaio Voges-Proskauer (VP) modificado em meio líquido Clark \& Lubs para fermentação de glicose. A produção de metabólitos foi avaliada em espectrofotômetro e apresentou grande variação nas concentrações $(0,476$ a 1,865$)$ para os diferentes isolados. As estirpes 241 , 320, 326 e 273 apresentaram valores superiores aos das demais testadas. De acordo com os resultados positivos no teste qualitativo de VP, 11 isolados foram escolhidos para os testes em meio mínimo contendo quitina como única fonte de carbono. Isolados que apresentaram formação de halo de degradação foram consideradas bactérias quitinolíticas, evidenciando atividade quitinase. Dentre essas cepas, duas pertenciam ao gênero Bacillus spp. (56 e 121) e dois para o gênero Enterobacter spp. (292 e 151). Portanto, o presente trabalho foi capaz de identificar cepas nativas com potencial para estudos de biocontrole permitindo continuar as investigações de outros metabólitos produzidos por essas bactérias nesta coleção no que diz respeito à proteção de plantas.

Palavras-chave: biocontrole; degradação de quitina; BPCP.

\section{Introduction}

In agricultural production systems, the improper utilization of pesticides has gradually promoted the loss and alteration in the diversity of plants, insects and natural microorganisms. This has led to functional imbalance and the selection of genetic resistance that promote establishing pests and diseases in commercial 
plants (BETTIOL; MORANDI, 2009; BRASIL, 2012; SILVA et al., 2015).

The sustainable cultivation of food has been motivating more researches that aim to develop knowledge about the control of phytopathogens to reduce the use of fungicides in the crops of economic importance. In this context, biological control consists of one alternative and advantageous means for the control of some plant diseases. Microorganism diversity is a tool to understand antagonistic relationships among or between the species, and essential to identify individuals with biotechnological potential for biocontrol (ZHANG et al., 2017).

In rhizosphere, plant growth-promoting bacteria (PGPB) act beneficially in the interaction with plants due to the ability to improve the plant performance. The PGPB demonstrated production of phytohormones, phosphate solubilization, nutrient mineralization and biological nitrogen fixation (BNF). Additionally, the PGPB presented indirect mechanisms by helping the population control of pathogenic microorganisms through the ecological relations, like competition and predation, in addition to the synthesis of compounds that promote the induction of systemic resistance (ISR) (HUNGRIA; ARAÚJO, 1994; HUNGRIA et al., 2010; FILGUEIRAS; MENESES, 2015; SPOLAOR et al., 2016). The microorganisms can use several mechanisms to inhibit the growth of pathogens. Among them, the production of antimicrobial substances, such as siderophores, $\beta-1,3$ glucanase, chitinases and antibiotics (MAKSIMOV et al., 2011; VIANA et al., 2013; PEREIRA; OLIVEIRA, 2016; CHANDRASEKARAN et al., 2017).

The most studied groups with potential for biocontrol are some species belonging to the genus Pseudomonas spp. and Bacillus spp., because of their capacity to produce antibiotics. Other bacteria of the genus Enterobacter spp. and Klebsiella also presents the potential of production of volatile organic compounds such as acetoin, involved in the induction of resistance against phytopathogens (HUNGRIA; ARAÚJO, 1994; RUDRAPPA et al., 2010; EGAMBERDIEVA et al., 2015). Pérez-Portuondo et al. (2017) verified that the production of acetoin by isolates of rhizosphere bacteria; it was demonstrated that the presence of this compound is involved in the induction of plant resistance.

Chitinase is a importance metabolite, an enzyme produced by microorganisms that promote the degradation of chitin, leading to breaking down the cell wall of fungi, by this way inhibit their growth (FAHEEM et al., 2015). Biologically active oligosaccharides, produced by chitin breaking bacteria, are compounds of a commercial interest with biotechnological potential as a resistance vegetable elicitor (EL HADRAMI et al., 2010; HAMID et al., 2013).

Research such as the Yasir et al. (2009), demonstrated the presence of chitinolytic activity for bacterial isolates present in the vermin compost substrate, which showed antifungal activity against Rhizoctoniasolani, Colletotrichumcoccodes, Pythium ultimum, Phytophthoracapsici and Fusariummoniliforme.

Therefore, contributes to the development of sustainable agriculture, the present study had as objective to evaluate native rhizobacteria to acetoin and chitinase production capacity in the soil of the west region of Paraná, using a modified Voges-Proskauer (VP) quantitative test, working with microvolumes.

\section{Material and methods \\ Obtention of isolates}

The strains were isolated from soil samples of 17 areas under different managements practices in the west region of Paraná (Table 1) and belong to the bacteria collection of the Grupo de Pesquisas em Fixação Biológica de Nitrogênio (FIXTEC) from Universidade Federal do Paraná (UFPR) - Setor Palotina. The determination of the genera of the isolates was carried out through partial sequencing of the 16S rRNA gene (SILVA, 2016). 
Table 1. Description of management type and collection site of soil samples from which the strains were isolated.

\begin{tabular}{ccc}
\hline Isolated & Source & Soil type \\
\hline 188 & Native forest & Eutrophic Red Oxisoil \\
10 & Agropastoral system & Dystrophic Red Latosoil \\
317 & Sugarcane monoculture with mineral fertilization & Eutrophic Red Argisoil \\
265 & Sugarcane monoculture with vinasse fertilization & Eutrophic Red Argisoil \\
320 & Succession corn - convetional soybean & Eutrophic Red Nitosoil \\
127 & Fallow with previous cultivation and sugarcane, corn and soybean & Dystrophic Red Latosoil \\
300 & Native forest & Eutrophic Red Argisoil \\
302 & Crotalaria & Eutrophic Red Argisoil \\
81 & Pasture & Eutrophic Red Nitosoil \\
15 & Agropastoral system & Eutrophic Red Latosoil \\
56 & Agropastoral system & Eutrophic Red Latosoil \\
102 & Corn - soybean succession & Eutrophic Red Nitosoil \\
121 & Native forest & Eutrophic Red Oxisoil \\
57 & Fallow with previous cultivation and sugarcane, corn and soybean & Dystrophic Red Latosoil \\
203 & Crotalaria & Eutrophic Red Argisoil \\
299 & Rotation with sugarcane, soybean and corn & Eutrophic Red Argisoil \\
326 & Fallow with previous cultivation and sugarcane, corn and soybean & Dystrophic Red Latosoil \\
273 & Sugarcane monoculture with vinasse fertilization & Eutrophic Red Argisoil \\
220 & Corn - soybean succession & Eutrophic Red Oxisol \\
142 & Succession corn - organic soybean & Eutrophic Red Oxisol \\
208 & Sugarcane monoculture with mineral fertilization & Eutrophic Red Argisole \\
152 & Native forest & Eutrophic Red Argisoil \\
130 & Succession corn - wheat & Eutrophic Red Oxisoil \\
194 & Succession corn - convetional soybean & Eutrophic Red Argisoil \\
241 & Sugarcane monoculture with vinasse fertilization & Eutrophic Red Nitosoil \\
24 & Native forest & Eutrophic Red Argisoil \\
151 & Crotalaria & Eutrophic Red Argisoil \\
292 & & Eutrophic Red Argisoil \\
\hline & &
\end{tabular}

\section{Qualitative and quantitative acetoin assays}

The detection of acetoin production was carried out utilizing the Barrit alpha-naphthol reagents, according to Clark and Lubs method (STELATO, 2011). Results interpretation was based on the culture medium coloration changes, pink to red for a positive result and copper colour for the negative one. The quantitative test was carried out following Voges-Proskauer's modified test (VP) (ROMICK; FLEMING, 1998). To obtain the acetoin standard curve, serial dilutions from the stock solution of pure acetoin (Sigma $\geq 96 \%$ ) were prepared 0,$1 ; 0,3 ; 0,5 ; 1 ; 2 ; 3 \mathrm{e} ; 4 \mathrm{mmol} / \mathrm{L}$, in triplicate with a volume of $2 \mu \mathrm{L}$. The acetoin production was recorded by reading in a Nanodrop2000 (Thermo Fischer ${ }^{\mathrm{TM}}$ ) at the wavelength of $490 \mathrm{~nm}$. The quantitative results of acetoin production were used for a cluster analysis using the WARD algorithm with the software Bionumerics (Applied Math) and a frequency analysis with software excel (Microsoft).

\section{Detection of chitinase production}

The culture medium utilized was described by Hsu e Lockwood (1975), it presents the chitin as only carbon's source. The chitin source utilized in this study was obtained from the purification of shrimp (MOURA et al., 2006). For homogeneous growth of colonies was used germinating paper that contained a liquid medium for bacterial growth previously sterilized in the autoclave. The paper was inserted in the centre of the plate that contained chitin medium. The test was realized in duplicate for each isolate and the plates were incubated in B.O.D for eight days at $27^{\circ} \mathrm{C}$. The strains that showed a halo of degradation around the disc were considered producers of the chitinase enzyme (HSU; LOCKWOOD, 1975). 


\section{Results and discussion}

From the total of 28 strains submitted to the acetoin quantification method, 25 of them produced positive results for the presence of this compound (Table 2). Between those, four presented reddish colour of high intensity, all of them belong to the genus Enterobacter (10, 127, 203 and 151 strains). According to Stelato (2011) and Sánchez et al. (2015), this is because the Enterobacter genus is typically used as a positive control for this test because of the high capacity of acetoin production, although some isolates in this work are not able to produce such a compound, as isolates 265, 152 and 142. The objective of the qualitative test was to confirm the presence of acetoin as a form of screening to send the samples to the quantitative test because it reduces the cost to realize a more complex method (FIGURE 1).

The quantitative results of acetoin of reduction are described in Table 2. Cluster analysis by ward method resulted in 6 classes regarding acetoin production (APPENDIX 1). The classes formed and the frequency of each class are summarized in table 3 .

Table 2. Results of qualitative and quantitative test for the acetoin and chitinase production by the strains of native rhizobacteria from the west region Paraná.

\begin{tabular}{|c|c|c|c|c|}
\hline GÊNUS & ISOLATED & $\begin{array}{l}\text { CHITINASEH } \\
\text { ALO }^{1}\end{array}$ & ACETOÍN ${ }^{2}$ & [C] ACETOÍN (mM) ${ }^{3}$ \\
\hline Paenibacillus sp. & 188 & - & + & 1,560 \\
\hline Enterobacter sp. & 10 & - & + & 1,226 \\
\hline Enterobacter sp. & 317 & - & + & 0,802 \\
\hline Enterobacter sp. & 265 & - & - & - \\
\hline Enterobacter sp. & 320 & - & + & 1,841 \\
\hline Enterobacter sp. & 127 & - & + & 1,365 \\
\hline Enterobacter sp. & 300 & - & + & 1,413 \\
\hline Enterobacter sp. & 302 & - & + & 0,825 \\
\hline Falsibacillus sp. & 81 & - & + & 1,627 \\
\hline Falsibacillus sp. & 15 & - & + & 0,905 \\
\hline Bacillus sp. & 56 & + & + & 1,508 \\
\hline Bacillus sp. & 102 & - & + & 1,103 \\
\hline Bacillus sp. & 121 & + & + & 1,333 \\
\hline Enterobacter sp. & 57 & - & + & 0,738 \\
\hline Enterobacter sp. & 203 & - & + & 1,302 \\
\hline Enterobacter sp. & 299 & - & + & 0,964 \\
\hline Enterobacter sp. & 326 & - & + & 2,142 \\
\hline Enterobacter sp. & 273 & - & + & 1,706 \\
\hline Enterobacter sp. & 220 & - & + & 0,440 \\
\hline Enterobacter sp. & 142 & - & - & - \\
\hline Enterobacter sp. & 208 & - & + & 0,539 \\
\hline Enterobacter sp. & 152 & - & - & - \\
\hline Enterobacter sp. & 130 & - & + & 0,857 \\
\hline Enterobacter sp. & 194 & - & + & 1,674 \\
\hline Enterobacter sp. & 241 & - & + & 1,865 \\
\hline Enterobacter sp. & 24 & - & + & 1,468 \\
\hline Enterobacter sp. & 151 & + & + & 1,380 \\
\hline Enterobacter sp. & 292 & + & + & 0,476 \\
\hline
\end{tabular}


Table 3. Frequency of classes of acetoin-producing bacteria.

\begin{tabular}{lrr}
\hline $\begin{array}{l}\text { Produção de Acetoína } \\
\text { (mM) }\end{array}$ & \multicolumn{2}{c}{$\begin{array}{l}\text { Frequencia de } \\
\text { Frequencia total }\end{array}$} \\
\hline $0-1$ & 12 & 11 \\
$1100-1200$ & 1 & 0 \\
$1201-1450$ & 7 & 6 \\
$1450-1800$ & 5 & 2 \\
$1801-1900$ & 2 & 2 \\
$1901-2200$ & 1 & 1 \\
\hline
\end{tabular}

Lee et al. (2012), reported good results in induced systemic resistance (ISR) in plants of the genus Arabidopsis with the rhizobacteria strain Paenibacillus, where the production of $0.008 \mathrm{mM}$ of acetoin was an effective for biocontrol. The strain 326 showed the highest value in the production of acetoin (2.142 mM), becoming a potential candidate or future studies of biocontrol.

The use of rhizobacteria in studies of induction of resistance in plants has been associated to reducing the damage caused by pathogens attack (VIANA et al., 2013). In the work of Rudrappa et al. (2010), it was observed a decrease in the severity of the attack of Pseudomonas syringae pv. tomato on Arabidopsis thaliana when inoculated with one isolate of Bacillus subtilis that can produce acetoin. In the opposite side, mutant strains with lower acetoin production, in that study, resulted in less control of the disease.

Eleven strains with higher production of acetoin were chosen for the chitin degradation assay. The strains that stood out as good candidates for chitinase production belonged to genus Bacillus (56 and 121) and Enterobacter (292 and 151).

Figure 1. Production of chitin degradation halo by the chitinase production in strains 151 and 292 belonging to the genus Enterobacter and in strains 56 and 121 belonging to the genus Bacillus of rhizobacteria from Western Paraná.

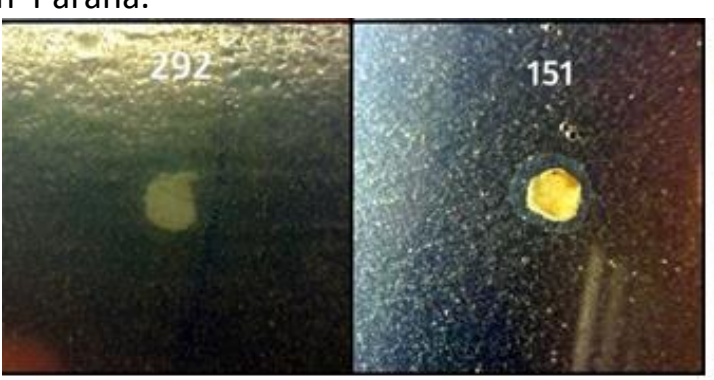

Several authors have already reported the production of chitinolytic enzymes by bacteria of those genera (WEN et al., 2002; SHALI et al., 2010; VELUSAMY; KIM, 2011). Liu et al. (2013) reported the genomic analysis of the strain Enterobacter cloacae subsp. cloacae ENHKU01, which is a PGP bacterium, allowed to demonstrate the presence of several genes related to mechanisms of antagonism to microorganisms, as bacteriocins, production of siderophores and chitinase, this last one found in strains in this work.

Use of Bacillus genera for biocontrol of plants diseases have been reported previously. Li et al. (2010) and Huang et al. (2012), reported

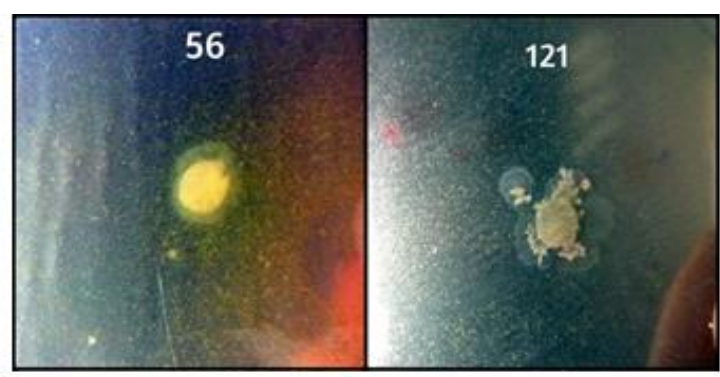

the use of the strain of Bacillus pumilus for control of the pathogen Rhizoctonia solani in cucumbers. Ji et al. (2013) demonstrated the ability of the Bacillus amyloliquefaciens strain to control a wide variety of fungi, including: Alternaria panax, Botrytis cinera, Colletotrichum orbiculare, Penicillium digitatum, Pyricularia grisea and Sclerotinia sclerotiorum.

According to studies, bacteria of the genus Bacillus present a large capacity for the production of compounds with antagonistic activity (MONTEIRO et al., 2005; HAN et al., 2015). Thus, isolates 151, 56, 292 and 121 can be applied in the biocontrol because of the capacity of forming halos of chitin degradation with ample 
reports of inhibition of the growth of phytopathogenic fungi (KEMPKA et al., 2008; SURYANTO et al., 2012; RAMPINO et al., 2013; ZALILA-KOLSI et al., 2016).

\section{Conclusions}

The modified Voges-Proskauer (VP) quantitative test proved to be a proper screening for the authentication of acetoin producing strains revealing the presence of the molecule in 25 of the 28 strains analyzed;

Among the 25 strains positive for the presence of acetoin, four isolates belonging to the Enterobacter genus (326, 241, 320 and 273) presented higher production of this metabolite, representing good candidates for ISR study in the biocontrol;

Isolates 151, 292, 56 and 121 belonging to the Enterobacter genus and isolates 56 and 121 belonging to the Bacillus genus were the only strains that presented halo of chitin degradation and could be better studied for use in the biocontrol of phytopathogens by the antagonistic attack.

\section{References}

BETTIOL, W.; MORANDI, M. A. B. Controle biológico de plantas no Brasil. 1. ed. JaguariúnaSP: Embrapa Meio Ambiente, 2009.

BRASIL. Ministério da Ciência, Tecnologia e Inovação. Estratégia nacional de ciência, tecnologia e inovação 2012 - 2015. Balanço das atividades estruturantes 2011, Brasilía: MCTI, 2012. 220 p.

CHANDRASEKARAN, M.; BELACHEW, A. T.; YOON, E.; CHUN, S. Expression of $\beta$-1,3-glucanase (GLU) and phenylalanine ammonia-lyase (PAL) genes and their enzymes in tomato plants induced after treatment with Bacillus subtilis CBR05 against Xanthomonas campestri spv. vesicatoria. Journal of General Plant Pathology, v. 83, n. 1, p. 7-13, 2017. https://doi.org/10.1007/s10327-016-0692$\underline{5}$

EGAMBERDIEVA, D.; SHRIVASTAVA, S.; VARMA, A. Plant-Growth-Promoting Rhizobacteria (PGPR) and Medicinal Plants. Soil Biology, v. 42, 2015. https://doi.org/10.1007/978-3-319-13401-7

EL HADRAMI, A. ADAM, L. R.; EL HADRAMI, I.; DAAYF, F. Chitosan in plant protection. Marine Drugs, v. 8, n. 4, p. 968-87, 2010.

\section{https://doi.org/10.3390/md8040968}

FAHEEM, M.; WASEEM, R.; WEI, Z. Evaluation of the biocontrol potential of Streptomyces goshikiensis YCXU against Fusarium oxysporum $\mathrm{f}$. sp. niveum. Biological Control, v. 81, n. 1, p. 101110,

2015. https://doi.org/10.1016/i.biocontrol.2014.11.012

FILGUEIRAS, L. M. B.; MENESES, C. H. S. G. Efeito das bactérias promotoras de crescimento de plantas na proteção contra o estresse hídrico. Journal of Biology \& Pharmacy and Agricultural Management, v. 11, n. 1, p. 21-30, 2015.

HAN, J. H.; SHIN, H.; SHIN, J. H.; KIM, K. S. Antagonistic Activities of Bacillus spp. Strains Isolated from Tidal Flat Sediment Towards Anthracnose Pathogens Colletotrichum acutatum and $C$. gloeosporioides in South Korea. The plant pathology journal, v. 31, n. 2, p. 165-175, 2015. https://doi.org/10.5423/PPJ.OA.03.2015.0036

HSU, S. C.; LOCKWOOD, J. L. Powdered chitin agar as a selective medium for enumeration of actinomycetes in water and soil. Applied and Environmental Microbiology, v. 29, n. 3, p. 422426,

1975.

https://doi.org/10.1128/AEM.29.3.422-426.1975

HUANG, X.; ZHANG, N.; YONG, X.; YANG, X.; SHEN, Q. Biocontrol of Rhizoctonia solani damping-off disease in cucumber with Bacillus pumilus SQR-N43. Microbiological Research, v. 167, n. 3, p. 135-143, 2012. https://doi.org/10.1016/j.micres.2011.06.002

HUNGRIA, M.; ARAÚJO, R. M. Manual de métodos empregados em estudos de microbiologia agrícola. Embrapa, 1994.

HUNGRIA, M.; CAMPO, R. J.; SOUZA, E. M.; PEDROSA, F. O. Inoculation with selected strains of Azospirillum brasilense and A. lipoferum improves yields of maize and wheat in Brazil. Plant and Soil, v. 331, n. 1-2, p. 413-425, 2010. https://doi.org/10.1007/s11104-009-0262-0

HAMID, R.; KHAN, M. A.; AHMAD, H.; ABDIN, M. Z.; MUSARRAT, J.; JAVED, S. Chitinases: An update. Journal of Pharmacy and Bioallied Sciences, v. 5, n. 1, p. 21-29, 2013. https://doi.org/10.4103/0975-7406.106559 
JI, S. H.; PAUL, N. C.; DENG, J. X.; KIM, Y. S.; YUN, B.; YU, S. H. Biocontrol Activity of Bacillus amyloliquefaciens CNU114001 against Fungal Plant Diseases. Mycobiology, v. 41, n. 4, p. 234242,

2013.

\section{https://doi.org/10.5941/MYCO.2013.41.4.234}

KEMPKA, A. P.; LIPKE, N. L.; PINHEIRO, L. F.; MENONCIN, S.; TREICHEL, H.; FREIRE, D. M.; DI LUCCIO, M.; OLIVEIRA, D. Response surface method to optimize the production and characterization of lipase from Penicillium verrucosum in solid-state fermentation. Bioprocess and Biosystems Engineering, v. 31, n. 2, p. 119-125, 2008. https://doi.org/10.1007/s00449-007-0154-8

LEE, B.; FARAG, M. A.; PARK, H. B.; KLOEPPER, J. W.; LEE, S. H.; RYU, C. Induced resistance by a long-chain bacterial volatile: elicitation of plant systemic defense by a C13 volatile produced by Paenibacillus polymyxa..Plos One, v.7, n. 11, p. 111,

2012.

https://doi.org/10.1371/journal.pone.0048744

LI, C. H.; ZHAO, M. W.; TANG, C. M.; LI, S. P. Population dynamics and identification of endophytic bacteria antagonistic toward plantpathogenic fungi in cotton root. Microbial ecology, v. 59, n. 2, p. 344-356, 2010. https://doi.org/10.1007/s00248-009-9570-4

LIU, W. Y.; WONG, C. F.; CHUNG, K. M. K.; JIANG, J. W.; LEUNG, F. C. C. Comparative genome analysis of Enterobacter cloacae. PLoS One, v. 8, n.9, 2013.

https://doi.org/10.1371/journal.pone.0074487

MAKSIMOV, I. V.; ABIZGIL'DINA, R. R.; PUSENKOVA, L. I. Plant growth promoting rhizobacteria as alternative to chemical crop protectors from pathogens. Applied Biochemistry and Microbiology, v. 47, n. 4, p. 333-345, 2011. https://doi.org/10.1134/S0003683811040090

MONTEIRO, L.; MARIANO, R. L. R.; MAIOR, A. M. S. Antagonism of Bacillus spp. against Xanthomonas campestres pv. campestris. Brazilian Archives of Biology and Technology, v. 48, n. 1, p. 23-29, 2005. https://doi.org/10.1590/S1516-

89132005000100004

MOURA, C. M.; MUSZINKI, P.; SCHMIDT, C.;
ALMEIDA, J.; PINTO, L. A. A. Quitina e quitosana produzidas a partir de resíduos de camarão e siri: avaliação do processo em escala piloto. VETOR Revista de Ciências Exatas e Engenharias, v. 16, n. 1, p. 37-45, 2006.

PEREIRA, E. L.; OLIVEIRA, A. F. A. A produção de antibióticos por processos fermentativos aeróbios. Revista da Universidade Vale do Rio Verde, Três Corações, v. 14, n. 2, p. 1058-1078, 2016. https://doi.org/10.5892/ruvrd.v14i2.3157

PÉREZ-PORTUONDO, I.; MERIÑO-REYES, L.; ÁBALOS-RODRÍGUEZ, A.; PÉREZ-SILVA, R. M. Características promotoras de crecimiento vegetal em rizobactérias aisladas de suelos contaminados com compuestos fenólicos. Revista Cubana de Química, v. 29, n. 1, p. 73-88, 2017.

RAMPINO, A.; BORGOGNA, M.; BLASI, P.; BELLICH, B.; CESARO, A. Chitosanna no particles: Preparation, sizeevolution and stability. International Journal of Pharmaceutics, v. 455, n. $1-2$, p. 219-228, 2013. https://doi.org/10.1016/j.ijpharm.2013.07.034

ROMICK, T. L.; FLEMING, H. P. Acetoin production as an indicator of growth and metabolic inhibition of Listeria monocytogenes. Journal of Applied Microbiology, v. 84, n. 1, p. 18-24, 1998. https://doi.org/10.1046/i.13652672.1997.00302.x

RUDRAPPA, T.; BIEDRZYCHI, M. L.; KUNJETI, S. G.; DONOFRIO, N. M.; CZYMMEK, K. J.; PARÉ, P.; BAIS, H. P. The rhizobacterial elicitor acetoin induces systemic resistance in Arabidopsis thaliana. Communicative and Integrative Biology, v. 3, n. 2, p. 130-138, 2010. https://doi.org/10.4161/cib.3.2.10584

SÁNCHEZ, A. A. D.; LÓPEZ, M. C.; ARIAS, M. B.; CASTAÑOLL, I. E.; ABREU, M. P.; MADRUGAL, R. C. F.; HERNÁNDEZ, M. C. P.; ZUBIAR, Y. M. Bacterias patógenas de larvas de Bombyxmori L. en áreas de reproducciónen Cuba. Revista de Protección Vegetal, v. 29, n. 3, p. 216, 2015

SILVA, Thaís Luft da. Prospecção de bactérias promotoras de crescimento vegetal. 2015. $51 \mathrm{f}$. TCC (Graduação) - Curso de Tecnologia em Biotecnologia, Universidade Federal do Paraná Setor Palotina, Palotina, 2016.

SILVA, J. M.; RUARO, L.; MALAFAIA, G.; PAZ-LIMA, 
M. L. Seleção in vitro populações de microrganismos antagonistas e relacionamento contra a fusariose-do-feijoeiro (Fusarium oxysporum sp. phaseoli). Global Science and Technology, Rio Verde, v. 8, n. 1, p. 96-109, 2015. https://doi.org/10.14688/1984-

3801/gst.v8n1p96-109

SHALI, A.; GHASEMI, S.; AHMADIAN, G.; RANJBAR, G.; DEHESTANI, A.; KHALESI, N.; MOTALLEBI, E.; VAHED, M. Bacillus pumilus SG2 chitinases induced and regulated by chitin, show inhibitory activity against Fusarium graminearum and Bipolaris sorokiniana. Phytoparasitica, v. 38, n. 2, p. 141-147, 2010. https://doi.org/10.1007/s12600-009-0078-8

SPOLAOR, L. T.; GONÇALVES, L. S. A.; SANTOS, O. J. A. P. D.; OLIVEIRA, A. L. M. D.; SCAPIM, C. A.; BERTAGNA, F. A. B.; KUKI, M. C. Plant growthpromoting bacteria associated with nitrogen fertilization at topdressing in popcorn agronomic performance. Bragantia, v. 75 , n. 1, p. 33-40, 2016. https://doi.org/10.1590/1678-4499.330

STELATO, M. C. R. M. M. Microbiologia prática: aplicações de aprendizagem de microbiologia básica, bactérias, fungos e vírus. 2. ed. São Paulo: Atheneu, 2011.

SURYANTO, D.; IRAWATI, N.; MUNIR, E. Isolation and Characterization of Chitinolytic Bacteria and Their Potential to Inhibit Plant Pathogenic Fungi. Microbiology Indonesia, v. 5, n. 3, p. 8, 2012. https://doi.org/10.5454/mi.5.3.8

VELUSAMY, P.; KIM, K. Y. Chitinolytic activity of Enterobacter sp. KB3 antagonistic to Rhizoctonia solani and its role in the degradation of living fungal hyphae. International Research Journal of Microbiology, v. 2, n. 6, p. 206-214, 2011.

VIANA, F. M. P.; LIMA, J. R.; FEITOZA, E. M. B. A. C.; MEDEIROS, R. A. F. Produção de Sideróforos por Leveduras Antagônicas. Fortaleza: Embrapa, 2013.

WEN, C. M.; TSENG, C. S.; CHENG, C. Y.; LI, Y. K. Purification, characterization and cloning of a chitinase from Bacillus sp. NCTU2. Biotechnology and Applied Biochemistry, v. 35, n. 3, p. 213-219, 2002. https://doi.org/10.1042/BA20020001

YASIR, M.; ASLAM, Z.; KIM, S. W.; LEE, S. W.; JEON, C. O.; CHUNG, Y. R. Bacterial community composition and chitinase gene diversity of vermicompost with antifungal activity. Bioresource Technology, v. 100, n. 19, p. 43964403, 2009. https://doi.org/10.1016/j.biortech.2009.04.015

ZALILA-KOLSI, I.; MAHMOUD, A. B.; ALI, H.; SELLAMI, S.; NASFI, Z.; TOUNSI, S.; JAMOUSSI, K. Antagonist effects of Bacillus spp. strains against Fusarium graminearum for protection of durum wheat (Triticum turgidum L. subsp. durum). Microbiological Research, v. 192, p. 148-158, 2016.

https://doi.org/10.1016/j.micres.2016.06.012

ZHANG, X.; ZHOU, Y.; LI, Y.; FU, X.; WANG, Q. Screening and characterization of endophytic Bacillus for biocontrol of grapevine downy mildew. Crop Protection, Elsevier, v. 96, n. 1, p. 173-179, 2017. https://doi.org/10.1016/i.cropro.2017.02.018 


\section{APPENDIX 1}

Cluster analysis of acetoin-producing bacteria using the WARD method.

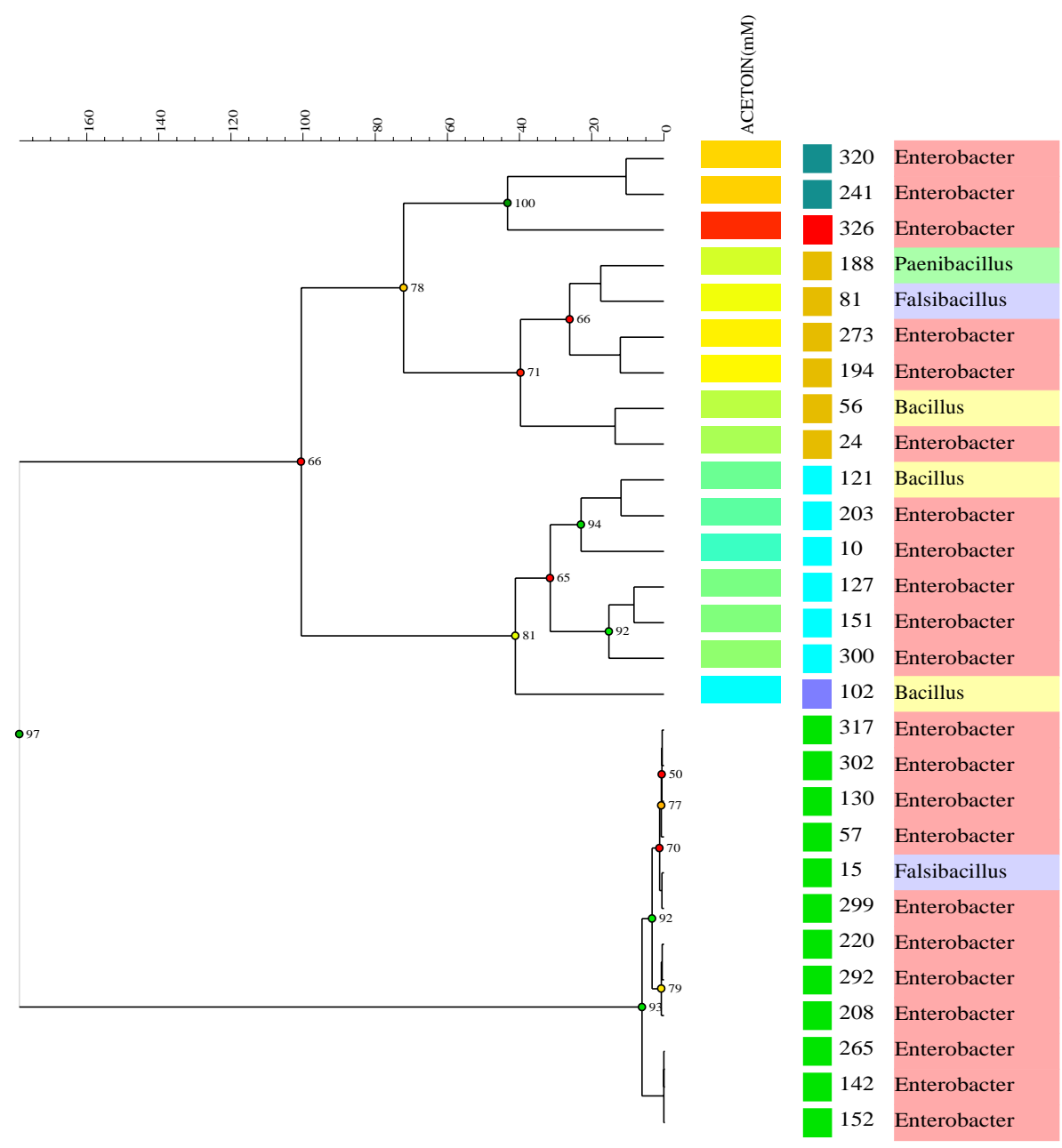

